\title{
Bryophytes and lichens in peatlands and Tepualia stipularis swamp forests of Isla Grande de Chiloé (Chile)
}

\author{
Carolina A. León ${ }^{1,2, *}$, Gisela Oliván ${ }^{1}$, Juan Larraín ${ }^{3}$, Reinaldo Vargas ${ }^{4}$ \& Esther Fuertes ${ }^{1}$ \\ ${ }^{1}$ Departamento Biología Vegetal I, Fac. C. Biológicas, Universidad Complutense de Madrid, España; leon.valdebenito@gmail.com \\ ${ }^{2}$ Centro de Investigación en Recursos Naturales y Sustentabilidad, Universidad Bernardo O’Higgins, Fábrica 1990, Santiago, Chile \\ ${ }^{3}$ Science \& Education, The Field Museum, 1400 South Lake Shore Dr., Chicago, IL 60605, U.S.A \\ ${ }^{4}$ Herbario Federico Johow, Departamento de Biología, Universidad Metropolitana de Ciencias de la Educación, José Pedro Alessandri 744, Santiago, Chile
}

\begin{abstract}
León, C.A., Oliván, G., Larraín, J., Vargas, R. \& Fuertes, E. 2014. Bryophytes and lichens in peatlands and Tepualia stipularis swamp forests of Isla Grande de Chiloé (Chile). Anales Jard. Bot. Madrid 71(1): e003.

One hundred and twenty-nine taxa of bryophytes and lichens were found in peatlands (Sphagnum bogs) and swamp forests of Tepualia stipularis of Isla Grande de Chiloé (Chile) $\left(41^{\circ}-43^{\circ} \mathrm{S}, 73^{\circ}-74^{\circ} \mathrm{W}\right)$. Forty eight percent of these species are endemic to southern South America. The range of most species spans from Los Rios Region to Magallanes Region. Fifty mosses, 52 liverworts, and 27 macrolichens were reported. Global and national distributions and habitat preferences are given for each species.
\end{abstract}

Keywords: mosses, liverworts, lichens, peatlands, geographic distribution, southern South America.

\section{INTRODUCTION}

Bryophytes and lichens play a key role in peatlands. They participate directly in the constitution of peat and in the maintenance of these ecosystems (Vitt \& Belland, 1995). In some types of peatlands, mosses, like Sphagnum L., cover almost completely the surface (Gignac \& al, 1991). Due to wetness levels and the often meager vascular plant cover, peatlands bring favorable conditions to bryophytes and contribute to a large extent to the diversity of moss and liverwort species, particularly in regions where peatlands are abundant (Minayeva, 2008). Also, in the Northern Hemisphere, the role of peatlands in the upkeep of lichenic diversity is very important (Lang \& al., 2009). Nevertheless, Minayeva (2008) reported that the species number of lichens present is quite low compared to the non-peatland lichen flora for any given region. Thus, the role of peatlands in maintaining lichen biodiversity is unclear.

Europe and North America have completed inventories of peatland floras (Malmer, 1962; Vitt \& Belland, 1995; Wheeler, 1993), and this has permitted them, among other things, to determine the species that indicate the type of peatland, to study their ecological niches and to assess its relations with environmental parameters (Vitt \& al., 1975, 1990; Gignac \& Vitt, 1990; Gignac \& al., 1991). Unfortunately, this is not the situation in southern cone South America. In Chile, studies on the floristic diversity of peatlands are scarce (San Martín \& al., 1999; Schlatter \& Schlatter, 2004; Teneb \& Dollenz, 2004; Teneb \& al.,

\section{Resumen}

León, C.A., Oliván, G., Larraín, J., Vargas, R. \& Fuertes, E. 2014. Briófitos y líquenes de turberas y tepuales de la Isla Grande de Chiloé (Chile). Anales Jard. Bot. Madrid 71(1): e003.

Se han encontrado un total de 129 taxones de briófitos y líquenes en turberas esfagnosas y bosques pantanosos de Tepualia stipularis de la Isla Grande de Chiloé (Chile) $\left(41^{\circ}-43^{\circ} \mathrm{S}, 73^{\circ}-74^{\circ} \mathrm{W}\right)$. El $48 \%$ de las especies reportadas son endémicas del sur de Sudamérica. La distribución más frecuente entre las especies encontradas comprende desde la Región de Los Ríos hasta la Región de Magallanes y Antártica Chilena. Se registraron 50 musgos, 52 hepáticas y 27 macrolíquenes. Se reportan además las distribuciones globales y nacionales, y preferencias de hábitats para las distintas especies.

Palabras clave: musgos, hepáticas, macrolíquenes, turberas, distribución geográfica, sur de Sudamérica.

2008; Kleinebecker \& al., 2010) and even scarcer are the studies on the bryophytes and macro-lichens (Díaz \& al., 2005, 2008; Villagra \& al., 2009).

In Chile, peatlands are widely distributed in the southern part of the country (Zegers \& al., 2006), and are important ecosystems from an ecological and economic point of view. In particular, in Isla Grande de Chiloé, located in insular Patagonia, large extensions of different types of these ecosystems can be found (Díaz \& al., 2008).

Our study focused on peatlands dominated by Sphagnum spp., of the Isla Grande de Chiloé and on swamp forests of Tepualia stipularis (Hook. \& Arn.) Griseb., aka "tepuales", which are strongly linked to these peatlands. In Chiloé, based on their origin, it is possible to find two types of Sphagnum peatlands: those originated after the retreat of glaciers, referred to in this paper as glaciogenic peatlands, and those originated after 1850 following the burning or cutting down of forests typical to flooded areas, locally known as "pomponales" (Zegers \& al., 2006), referred to as secondary or anthropogenic peatlands in here.

Tepuales are dominated by Tepualia stipularis ("Tepú", Myrtaceae), which sometimes can be accompanied by Podocarpus nubigenus Lindl. ("Mañío Macho", Podocarpaceae), Pilgerodendron uviferum (D.Don.) Florin. ("Guaytecas Cypress", Cupressaceae) and/or Drimys winteri J.R. Forst. \& G. Forst. ("Canelo", Winteraceae). These forests develop in swampy water-saturated areas (García \& Ormazabal, 2008) and may accumulate organic material (Veblen \& Schlegel, 1982). As has been pointed out, cutting 
down these forests could have resulted in the aforementioned anthropogenic peatlands (Zegers \& al., 2006). Thus, the origin is a relevant factor for its floristic characterization. In addition, there are studies that show that the vascular and bryophytic floras of peatlands and tepuales are the same (Villagrán \& Barrera, 2002; Villagrán \& al., $2002,2003,2005)$, and therefore we think that stating the differences and similarities between both ecosystems is relevant.

This study contributes to the knowledge of the bryolichenic flora through achieving three central objectives: i) a floristic inventory of the mosses, liverworts and macrolichens present in glaciogenic and anthropogenic peatlands and tepuales of Isla Grande de Chiloé; ii) an evaluation of floristic differences and similarities among these three closely related communities, and iii) the study of the main ecological and biogeographical features of this flora, assessing the habitats, micro-habitats and patterns of geographical distribution of the species found. Being our main aim to establish the basis necessary to understand the ecological relations between the vegetation of these wetlands and its environment.

\section{MATERIALS AND METHODS}

Isla Grande de Chiloé, Los Lagos Region, Chile, is our study area $\left(42^{\circ}-43^{\circ} \mathrm{S} ; 73^{\circ}-75^{\circ} \mathrm{W}\right)$. Chiloé's climate is wet temperate with a strong oceanic influence (di Castri \& Hajek, 1976). Mean summer temperature is $10.2^{\circ} \mathrm{C}$ and mean winter temperature is $6.2^{\circ} \mathrm{C}$ (Pérez \& al., 2003). Annual rainfall fluctuates between 1,900 and 2,300 mm (CONAF, 2009), reaching 5,000-6,000 $\mathrm{mm}$ in montane areas (Pérez \& al., 2003).

Ten sites located in the northern and central parts of the island were selected (Fig. 1). Three study areas represented glaciogenic peatlands: Río Negro (RN), Los Caulles (CA) and Púlpito (PL); five studied areas represented anthropogenic peatlands: Senda Darwin (SD), Lecam (LC), Pumanzano (PM), Río Chepu (CH) and Teguel (TG); and two study areas represented tepuales: Senda Darwin (SD) and Chiloé National Park (CU).

Specimens were carefully determined according to morphological characters, and their characteristics were compared with the literature and herbarium specimens (including types). For lichens, chemical characters were also used. Lichen substances were identified using thin layer chromatography (TLC) following the protocol of White \& James (1985). Specimens were deposited in MACB and CONC and in Carolina León's personal collection. Detailed information on studied specimens and their localities is listed in the supplementary material.

The nomenclature follows Müller (2009) for mosses, except for Racomitrium geronticum Müll. Hal. (Larraín, 2012), and Hymenodontopsis mnioides (Hook.) N.E. Bell, A.E. Newton \& D. Quandt (Bell \& al., 2007); Hässel de Menéndez \& Rubies (2009) for liverworts, and Galloway \& Quilhot (1998), Feuerer (2012), and Index Fungorum (CABI Bioscience \& al., 2012) for lichens. The list of species has been arranged taxonomically in families following the criteria of Goffinet \& al. $(2008,2011)$ for mosses, except for the species Rhaphidorrbynchium callidum (Mont.) Broth., which follows the Tropicos database (Missouri Botanical Garden, 2014). For liverworts, the classification proposed by Crandall-Stotler \& al. (2009) and Stotler \& CrandallStotler (2011) was followed. For macro-lichens, we used the classification suggested by the Index Fungorum (CABI Bioscience \& al., 2012).

To establish the patterns of the global distribution of each of these species, an adaptation of the patterns proposed by Villagrán \& al. (2005) and Seki (1974) was done. The distributional ranges used are: Austral-Antarctic (A), which is equivalent to the pattern type of Nothofagus of Seki (1974) ranging from southern South America, to southern Australia (including Tasmania) and New Zealand; American (AM), limited to the American continent; Bipolar (B) species that are widely distributed in the circumboreal region and disjunct with southern South America and Antarctica; CircumSubantarctic (C), which includes the Austral-Antarctic continental and insular territory between latitudes $40^{\circ}$ and $84^{\circ} \mathrm{S}$; Cosmopolitan (COS), species which are widely distributed around the world; Endemic (E), their ranges cover southern Chile and Argentina, mainly restricted to temperate rainforests of southern South America, including Tierra del Fuego, Falkland Islands, South Georgia and the Antarctic peninsula; African (F), species which cover South America and Africa; Neotropical (N), the species under this pattern are disjunct with distant territories of tropical America, like the oriental Andes of Peru and Bolivia, southern Brazil, northern Andes; Pantropical-type Podocarpus (PAN), their ranges cover temperate and tropical areas of the world, like South America, southern Africa, Australasia and Indo-Malaysia.

The patterns of distribution in Chile followed those laid down by Villagrán \& al. (2005) with some modifications. The patterns used were: Xeromorphic $(\mathrm{X})$, from the northern border of the country to the interfluvial area of Choapa (Coquimbo Region) -Petorca (Valparaíso Region) $\left(17^{\circ}-33^{\circ} \mathrm{S}\right)$; Mediterranean $(\mathrm{M})$, which expands from the interfluvial areas of Choapa-Petorca to the Biobío river $\left(33^{\circ}-37^{\circ} \mathrm{S}\right)$; Valdivian (V), from Biobío to Chiloé $\left(37^{\circ}-43^{\circ} \mathrm{S}\right)$; Nord-Patagonian $(\mathrm{N})$, from Chiloé to Aysén $\left(43^{\circ}-49^{\circ} \mathrm{S}\right)$; and Subantarctic (S), from Aysén to Cape Horn $\left(49^{\circ}-56^{\circ} \mathrm{S}\right)$. In addition, ranges disjunct with Central Chile (CCh), Easter Island (EI), Juan Fernández Archipelago (JF), Fray Jorge and Talinay Forests (R), and Magallanes (Ma) are indicated. Species for which Chiloé represents their northernmost limit (NL) are also highlighted.

\section{RESULTS}

In total, 129 species have been identified, of which 50 were mosses, 52 liverworts, and 27 macro-lichens (Table 1). The anthropogenic peatlands are the most species rich habitat, adding up to 73 species. In second place come the glaciogenic peatlands, where 70 species were reported. Finally, the tepuales present 59 species in total.

Liverworts and mosses were found with similar frequencies in glaciogenic peatlands, whereas mosses were slightly more frequent in anthropogenic peatlands, and liverworts dominated tepuales (Fig. 2).

From a worldwide distribution perspective, the majority of taxa identified are endemic $(48 \%)$ and restricted to southern South American temperate rainforests. Secondly come species with bipolar distribution, followed by AustralAntarctic species and cosmopolitan ones respectively. The remaining species are found in other cold-temperate areas 


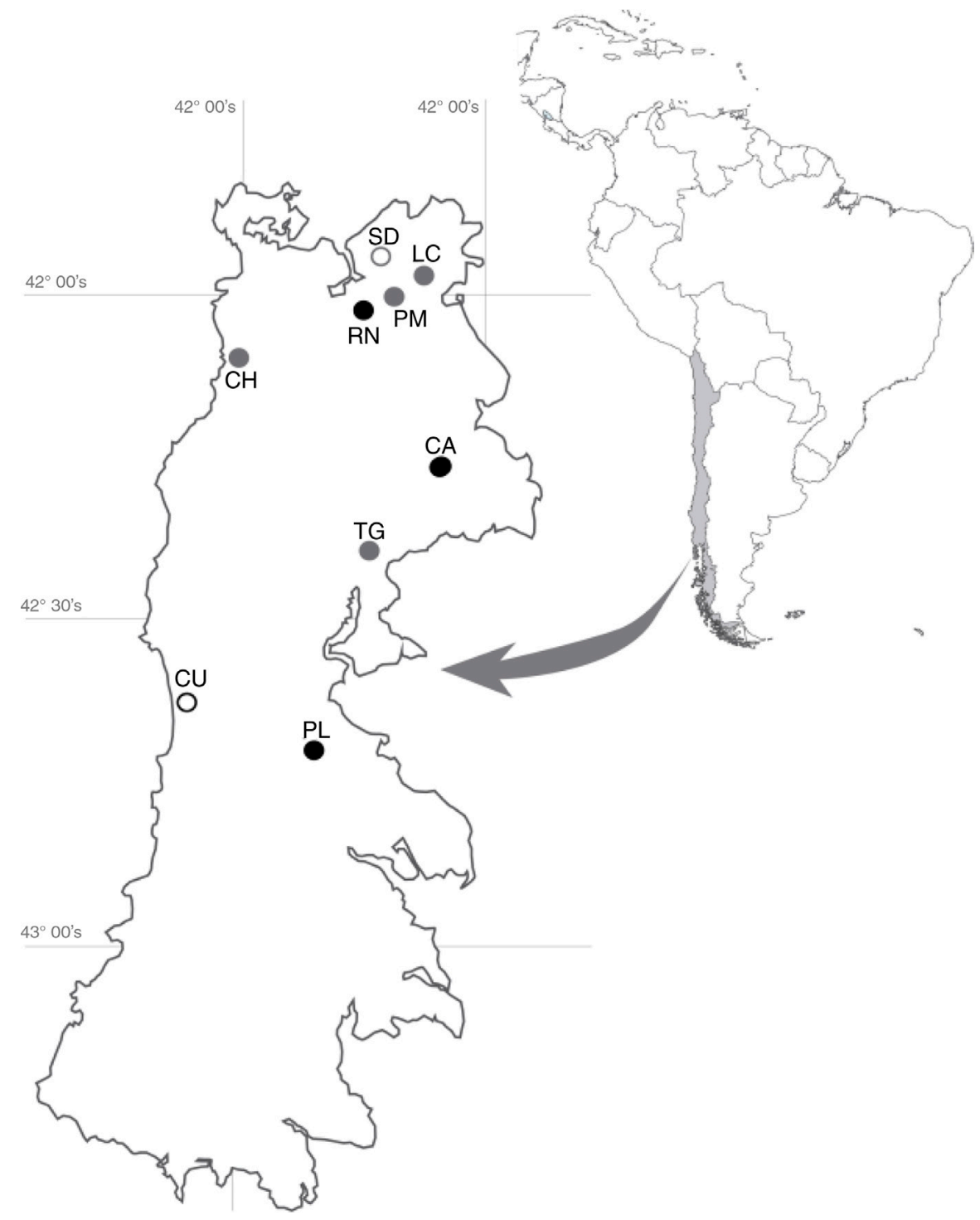

Fig. 1. Map of Chiloé, showing the studied localities. Glaciogenic peatlands: PL, Púlpito; RN, Rio Negro; CA, Caulles. Anthropogenic peatlands: SD, Senda Darwin; CH, Chepu; PM, Pumanzano; LC, Lecam; TG, Teguel. Tepuales: SD, Senda Darwin; CU, Chiloé National Park.

and in tropical belts throughout the world (Fig. 3A). When a more detailed analysis of habitat preference by organism type is done, the dominance of species endemic to southern South America reappears as a pattern.

The analysis of the distribution patterns in Chile of all studied species evidences that the majority of the taxa have a Valdivian-Nord Patagonic-Subantarctic distribution (VNS) (Fig. 3B). With regards to the analysis of habitat preference by organism type, the same trend can be seen, though with different degrees of dominance. Liverworts show the more distinct VNS pattern, and the species of this group do not show xeromorphic or Mediterranean patterns, in contrast with macrolichens, for which xeromorphic or Mediterranean taxa exist. Mosses on average have wider distribution patterns: $13 \%$ of its species are widely distributed in Chile. It is worth highlighting that seven of the studied species have at Isla Grande de Chiloé their northern-most distribution limit.

Different dominant species were registered in each of the habitats. There is a large proportion of rare species: sixty nine taxa were found only in one type of habitat. Nevertheless, common species were registered in at least two of the three habitat types sampled, and sixteen of them were common to the three types of habitats, e.g., Dicranoloma billardierei, Jamesoniella colorata and Cladonia squamosa. Even though the type of habitat with the largest number of species was the anthropogenic peatland, the tepuales presented the greatest amount of exclusive species.

\section{DISCUSSION}

Peatlands are vitally important to the biodiversity of the planet and provide a haven for a wealth of unusual and specially adapted organisms (Charman, 2002). According to our results, the number of species registered in this study clearly shows the relevance of these ecosystems in the conservation of biodiversity, especially in Chiloé, where peatlands and tepuales represent a low percentage of the area of the island. 
Table 1. Bryophyte and macro-lichen distribution in peatlands and tepuales of Chiloé. Global distribution patterns: Austral-Antarctic (A), American (AM), Bipolar (B), circum-Subantarctic (C), Cosmopolitan (COS), Endemic to southern South America (E), shared with Africa (F), Neotropical (N), Pantropical (PAN). Local (Chilean) distribution patterns: disjunct with Central Chile (CCh), disjunct with Easter Island (EI), disjunct with the Juan Fernández Archipelago (JF), Mediterranean (M), disjunct with Magallanes Region (Ma), Nord-Patagonian (N), north-most limit (NL), disjunct with Fray Jorge Forest (R), Subantarctic (S), Valdivian (V), Xeromorphic (X). Preferred habitats: anthropogenic peatland (AP), tepuales (TF), glaciogenic peatland (GP). Preferred microhabitats: tree base (BA), bryophyte carpet (CB), corticolous (Co), epiphyllous (EP), semisubmerged in pool (PP), completely submerged in pool (PS), forest floor (SB), peatland floor (herbarium material with no other specification; ST), peatland water-saturated floor (STA), on feces in peatland floor (STF), on bonfire rests in peatland floor (STFo), humid peatland floor (STH), dry peatland floor (STS).

\begin{tabular}{|c|c|c|c|c|c|c|}
\hline \multirow[b]{2}{*}{ Group } & \multirow[b]{2}{*}{ Family } & \multirow[b]{2}{*}{ Taxon } & \multicolumn{2}{|c|}{ Distribution } & \multicolumn{2}{|c|}{ Habitat } \\
\hline & & & Global & Local & Macro & Micro \\
\hline \multirow[t]{26}{*}{ Mosses } & Sphagnaceae & Sphagnum cf. capillifolium (Ehrh.) Hedw. & $\cos$ & V & $A P$ & ST \\
\hline & & Sphagnum fimbriatum Wilson & B & VNS & GP-AP-TF & STS, SB \\
\hline & & Sphagnum magellanicum Brid. & $\cos$ & VNS & GP-AP-TF & STA, SB \\
\hline & & Sphagnum cf. subsecundum Nees & B & V & $\mathrm{AP}$ & STA \\
\hline & Grimmiaceae & Racomitrium geronticum Müll. Hal. & B & VNS - JF & GP & STS \\
\hline & Dicranaceae & $\begin{array}{l}\text { Campylopus aureonitens subsp. recurvifolius (Dusén) } \\
\text { J.-P. Frahm }\end{array}$ & $E$ & MV & GP & PP \\
\hline & & Campylopus acuminatus Mitt. & A & VNS & GP-AP & STS, PS \\
\hline & & Campylopus incrassatus Müll. Hal. & A & MVNS & AP & STS \\
\hline & & $\begin{array}{l}\text { Chorisodontium aciphyllum (Hook. f. \& Wilson) } \\
\text { Broth. }\end{array}$ & A & VNS-JF & GP & ST \\
\hline & & Dicranella circinata Herzog & $\mathrm{E}$ & V & GP-AP & STA \\
\hline & & Dicranoloma billardierei (Brid. ex Anon.) Paris & PAN & MVNS-JF & GP-AP-TF & STS \\
\hline & & Dicranoloma imponens (Mont.) Renauld & A & VNS & GP-AP & STS \\
\hline & & Dicranoloma robustum (Hook. f. \& Wilson) Paris & A & VNS & GP-AP & $\mathrm{Co}$ \\
\hline & & Eucamptodon perichaetialis (Mont.) Mont. & $E$ & MVNS-JF & GP-AP & $\mathrm{Co}$ \\
\hline & Pottiaceae & $\begin{array}{l}\text { Leptodontium longicaule var. microruncinatum } \\
\text { (Dusén) R.H. Zander }\end{array}$ & AM & MVNS-JF & AP & STS \\
\hline & Splachnaceae & Tayloria stenophysata (Herzog) A.K. Kop. & $E$ & VNS & GP & STF \\
\hline & & Breutelia subplicata Broth. & $\mathrm{E}$ & MVNS & GP-AP-TF & STH \\
\hline & & Conostomum pentastichum (Brid.) Lindb. & C & VNS & AP & STS \\
\hline & Orthotrichaceae & Ulota cf. rufula (Mitt.) A. Jaeger & $\mathrm{E}$ & VN-JF & GP & Co \\
\hline & & $\begin{array}{l}\text { Zygodon hookeri var. leptobolax (Müll. Hal.) } \\
\text { Calabrese }\end{array}$ & $\mathrm{E}$ & MVNS & GP & Co \\
\hline & & Zygodon pentastichus (Mont.) Müll. Hal. & $\mathrm{E}$ & MVNS-JF & GP & $\mathrm{Co}$ \\
\hline & Rhizogoniaceae & $\begin{array}{l}\text { Hymenodontopsis mnioides (Hook.) N.E. Bell, } \\
\text { A.E. Newton \& D. Quandt }\end{array}$ & $\mathrm{B}$ & MVNS-JF & TF & SB \\
\hline & Ptychomniaceae & $\begin{array}{l}\text { Ptychomniella ptychocarpa (Schwägr.) } \\
\text { W.R. Buck\& al. }\end{array}$ & $\mathrm{E}$ & MVNS-JF & GP-TF & SB \\
\hline & & Ptychomnion cygnisetum (Müll. Hal.) Kindb. & $\mathrm{E}$ & XMEVNS-JF & GP-AP-TF & STS, SB \\
\hline & & Ptychomnion densifolium (Brid.) A. Jaeger & C & VNS & GP-AP & STS \\
\hline & Hypopterygiaceae & Dendrohypopterygium arbuscula (Brid.) Kruijer & $\mathrm{E}$ & MVNS-JF & TF & SB \\
\hline
\end{tabular}


Table 1. (Continuation)

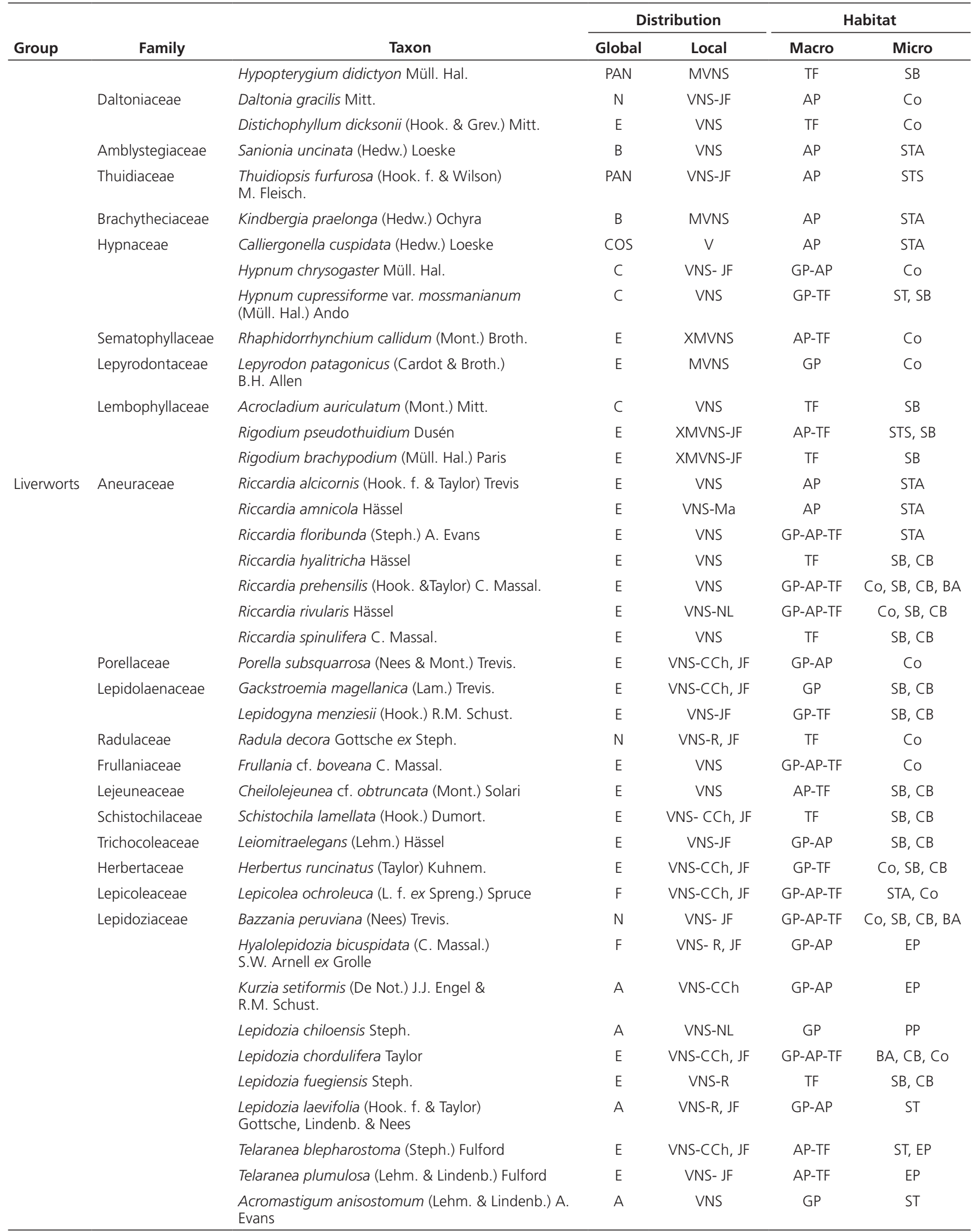


Table 1. (Continuation)

\begin{tabular}{|c|c|c|c|c|c|c|}
\hline \multirow[b]{2}{*}{ Group } & \multirow[b]{2}{*}{ Family } & \multirow[b]{2}{*}{ Taxon } & \multicolumn{2}{|c|}{ Distribution } & \multicolumn{2}{|c|}{ Habitat } \\
\hline & & & Global & Local & Macro & Micro \\
\hline & Lophocoleaceae & $\begin{array}{l}\text { Chiloscyphus attenuatus (Steph.) J.J. Engel \& } \\
\text { R.M. Schust. }\end{array}$ & $\mathrm{E}$ & VNS-JF & $\mathrm{TF}$ & $S B, C P$ \\
\hline & & $\begin{array}{l}\text { Chiloscyphus breutelii (Gottsche) J.J. Engel \& } \\
\text { R.M. Schust. }\end{array}$ & $\mathrm{N}$ & V & TF & $S B, C P$ \\
\hline & & Chiloscyphus horizontalis (Hook.) Nees & $\mathrm{E}$ & VNS & $\mathrm{TF}$ & $S B, C P$ \\
\hline & & Chiloscyphus humilis (Hook. f. \& Taylor) Hässel & C & VNS-JF & GP & $P P, B A$ \\
\hline & & Chiloscyphus magellanicus Steph. & $\mathrm{E}$ & VNS-JF & GP-TF & $S B, B A, C B$ \\
\hline & & Chiloscyphus striatellus C. Massal. & $\mathrm{E}$ & VNS & GP-TF & $S B, C P$ \\
\hline & & $\begin{array}{l}\text { Chiloscyphus subviridis (Hook. f. \& Taylor) } \\
\text { J.J. Engel \& R.M. Schust. }\end{array}$ & E & VNS-CCh, JF & GP & $S B, C P$ \\
\hline & & Leptoscyphus huidobroanus (Mont.) Gottsche & $\mathrm{E}$ & VNS & GP-AP-TF & $S B, C P$ \\
\hline & Plagiochilaceae & Plagiochila chonotica Taylor & $\mathrm{E}$ & VNS & TF & $\mathrm{SB}, \mathrm{CP}$ \\
\hline & & Plagiochila hookeriana Lindenb. & $\mathrm{E}$ & VNS-JF & TF & $\mathrm{SB}, \mathrm{CP}$ \\
\hline & & Plagiochila lechleri Gottsche & $\mathrm{E}$ & VNS-Ma & AP & $S B, C P$ \\
\hline & & Plagiochila lophocoleoides Mont. & E & VNS & TF & $S B, C P$ \\
\hline & & Plagiochila rubescens (Lehm. \& Lindenb.) Lindenb. & $\mathrm{E}$ & $\mathrm{VN}-\mathrm{CCh}, \mathrm{JF}$ & TF & $S B, C P$ \\
\hline & & Plagiochila stictaecola Mont. \& Gottsche & $\mathrm{E}$ & VNS & GP & BA \\
\hline & & Plagiochila subpectinata Besch. \& C. Massal. & $\mathrm{E}$ & VNS-R & AP-TF & $S B, C P$ \\
\hline & Jamesoniellaceae & Cryptochila grandiflora (Lindenb. \& Gottsche) Grolle & PAN & VNS-JF & GP & ST \\
\hline & & Jamesoniella colorata (Lehm.) Steph. & C & VNS-CCh, JF & GP-AP-TF & STS, Co, CB \\
\hline & & Nothostrepta bifida (Steph.) R.M. Schust. & $\mathrm{E}$ & VNS-JF & AP & $C B$ \\
\hline & Cephaloziaceae & Cephalozia skottsbergii Steph. & $\mathrm{E}$ & VNS-Ma-NL & GP-AP & ST, EP \\
\hline & Scapaniaceae & Anastrophyllum schismoides (Mont.) Steph. & A & VNS & GP & STH \\
\hline & Balantiopsidaceae & Balantiopsis asymmetrica (Herzog) J.J. Engel & E & VNS-JF & AP-TF & $C B, B A$ \\
\hline & & Balantiopsis cancellata (Nees) Steph. & $\mathrm{E}$ & VNS-CCh, JF & GP-AP & $B A, C B$ \\
\hline & & Isotachis madida (Hook. f. \& Taylor) Mitt. & $\mathrm{E}$ & VNS- CCh & AP & STS \\
\hline & Calypogeiaceae & $\begin{array}{l}\text { Calypogeia sphagnicola (Arnell \& J. Perss.) Warnst. } \\
\text { \& Loeske }\end{array}$ & B & VNS-Ma-NL & GP-AP & ST, EP \\
\hline & Geocalycaceae & Saccogynidium australe (Mitt.) Grolle & A & VNS-JF & AP & ST, EP \\
\hline \multirow[t]{15}{*}{ Lichens } & Cladoniaceae & Cladia aggregata (Sw.) Nyl. & PAN & VNS-JF & GP-AP & STH, BA \\
\hline & & Cladonia arbuscula (Wallr.) Flot. & B & VNS & GP-AP & ST \\
\hline & & Cladonia bellidiflora (Ach.) Schaer. & B & VNS-NL & GP-AP & ST \\
\hline & & Cladonia cenotea (Ach.) Schaer. & B & VNS-Ma-NL & GP & ST \\
\hline & & Cladonia chlorophaea (Flörke ex Sommerf.) Spreng. & $\cos$ & VNS-JF & $\mathrm{TF}$ & Co \\
\hline & & Cladonia gracilis subsp. elongata (Wulfen) Vain. & B & VNS-JF & AP-TF & ST \\
\hline & & Cladonialepidophora Ahti \& Kashiw. & $\mathrm{E}$ & VNS-JF & GP-AP & ST \\
\hline & & Cladonia macilenta Hoffm. & $\cos$ & VNS-JF & AP-TF & Co \\
\hline & & Cladonia mitis Sandst. & B & VNS & GP-AP & ST \\
\hline & & Cladonia pycnoclada (Pers.) Nyl. & $\mathrm{E}$ & MVNS-JF & GP-AP & ST \\
\hline & & Cladonia scabriuscula (Delise) Leight. & $\cos$ & VNS-JF & $A P$ & ST \\
\hline & & Cladonia squamosa (Scop.) Hoffm. & $\cos$ & VNS-JF & GP-AP-TF & ST \\
\hline & & Cladonia subsubulata Nyl. & B & VNS-JF-NL & AP & STH \\
\hline & Lobariaceae & $\begin{array}{l}\text { Pseudocyphellaria berberina (G. Forst.) } \\
\text { D.J. Galloway \& P. James }\end{array}$ & E & VNS-JF-R & GP-TF & Co \\
\hline & & Pseudocyphellaria crocata (L.) Vain. & $\cos$ & MVNS-JF, R & TF & Co \\
\hline
\end{tabular}


Table 1. (Continuation)

\begin{tabular}{|c|c|c|c|c|c|c|}
\hline \multirow[b]{2}{*}{ Group } & \multirow[b]{2}{*}{ Family } & \multirow[b]{2}{*}{ Taxon } & \multicolumn{2}{|c|}{ Distribution } & \multicolumn{2}{|c|}{ Habitat } \\
\hline & & & Global & Local & Macro & Micro \\
\hline & & Pseudocyphellaria divulsa (Taylor) Imshaug & $\mathrm{E}$ & VNS & AP & Co \\
\hline & & Pseudocyphellaria faveolata (Delise) Malme & A & VNS & TF & Co \\
\hline & & Pseudocyphellaria flavicans (Hook. f. \& Taylor) Vain. & $\mathrm{E}$ & VNS-JF & GP-TF & Co \\
\hline & & Pseudocyphellaria valdiviana (Nyl.) Follmann & E & VSN & TF & $\mathrm{Co}$ \\
\hline & & Sticta caulescens De Not. & E & VSN & TF & Co \\
\hline & & Sticta hypochra Vain. & $E$ & VSN & TF & Co \\
\hline & Parmeliaceae & Hypogymnia subphysodes (Kremp.) Filson & A & MVNS & GP-AP & Co \\
\hline & & Parmotrema reticulatum (Taylor) M. Choisy & $\cos$ & XMVNS-JF, R, El & $\mathrm{AP}$ & Co \\
\hline & Peltigeraceae & Peltigera didactyla (With.) J. R. Laundon & $\cos$ & VNS & AP & STS \\
\hline & & Peltigera polydactylon (Neck.) Hoffm. & $\cos$ & VNS-R & AP & STS \\
\hline & Sphaerophoraceae & Bunodophoron patagonicum (C.W. Dodge) Wedin & A & VNS & $\mathrm{TF}$ & Co \\
\hline
\end{tabular}

In a study complementing the one presented here we have reported three species and one sub-species new to Chiloé Province, five species new to los Lagos Region and one species new to Chile; thus highlighting the importance of these wetlands in the context of Chilean biodiversity (León \& al., 2013).

On the other hand, a high number of species shown in this work could have been influenced by environmental elements -including the presence of rare or vagrant species - and the heterogeneity of the landscape (Halffter \& Moreno, 2005). Sixty of the mentioned species were documented just for one place, which could result from community structural complexity, as previously seen in tropical forests (Halffter \& Moreno, 2005).

The heterogeneity of the landscape and, in particular, the heterogeneity of the microhabitat, has an important effect on the species registered in each habitat type, especially in in the case of glaciogenic and anthropogenic peatlands. The vertical gradient, which translates into a microtopographic or microstructural division, embraces from pools and water saturated depressions to dry hummocks. This is one of the most relevant factors when assessing the specific richness

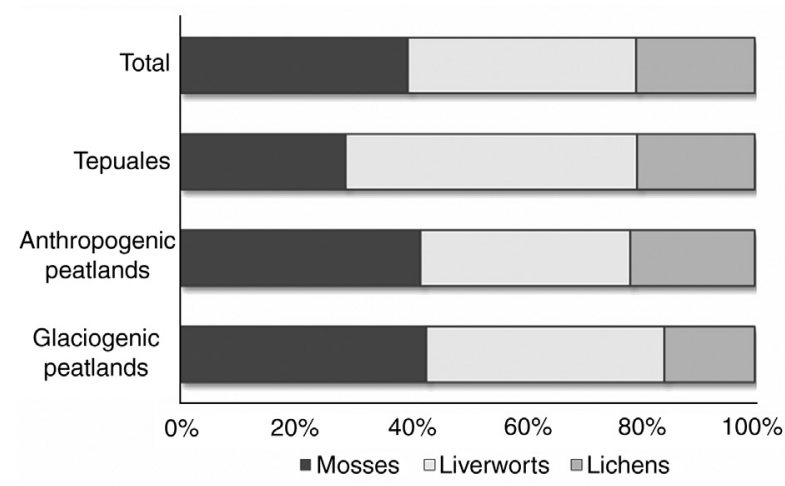

Fig. 2. Percentage of mosses, liverworts, and macro-lichens in total and in each of the types of habitats. and the floristic composition (Andrus \& al., 1983; Wheeler, 1993; Wheeler \& Proctor, 2000; Rydin \& Jeglum, 2006). The latter is not applicable to tepuales, where the bryophytic carpet is homogeneous.

In addition, there are environmental factors that may also heavily influence the composition of the bryophyte and lichen species in these ecosystems. León (2012) established that the chemical composition of water affects significantly the occurrence of the species of the cryptogamic groups under study.

After comparing the floristic results obtained here with results already published for ombrotrophic peatlands in the Northern Hemisphere, the low number of Sphagnum species in the studied area stands out: only six, a number much lower than that established for Canada (Vitt \& Belland, 1995) or Great Britain (Wheeler, 1993). It is important to note that in Chile no taxonomical review of the genus Sphagnum has been carried out, so the number of reported species could vary after further studies.

Another contrasting result is the high number of species of liverworts present in the peatlands of Chiloé in comparison to those in the Northern Hemisphere. For instance, Vitt \& Belland (1995) reported 20 species of liverworts in Canadian peatlands, and Wheeler (1993) pointed out 17 species of liverworts in British bogs. The specific richness of both is significantly surpassed by the 30 taxa found in Chiloé. Nevertheless, the low number of liverworts that has been historically documented could be partially explained by the generalized lack of knowledge of this group. Although the Boreal peatlands are very well characterized, studies that include liverworts are scarce (Kleinebecker \& al., 2008).

Vitt \& Belland (1995) have stated that in the Canadian peatlands an important percentage of species have a high fidelity to a certain type of peatland. These authors refer to the utility of bryophytes as indicator species for the classification of these ecosystems. In the case of Chiloé, despite having observed the fidelity of some species to a type of habitat, further studies are necessary to identify with certainty the species that can serve as indicators for the classification of peatlands. 
A

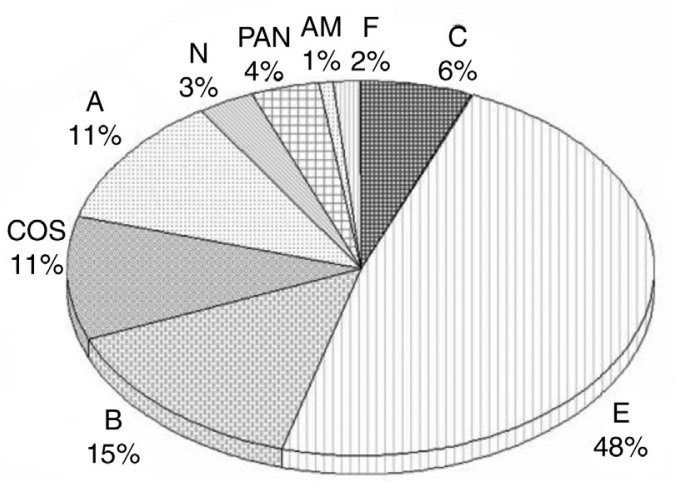

B

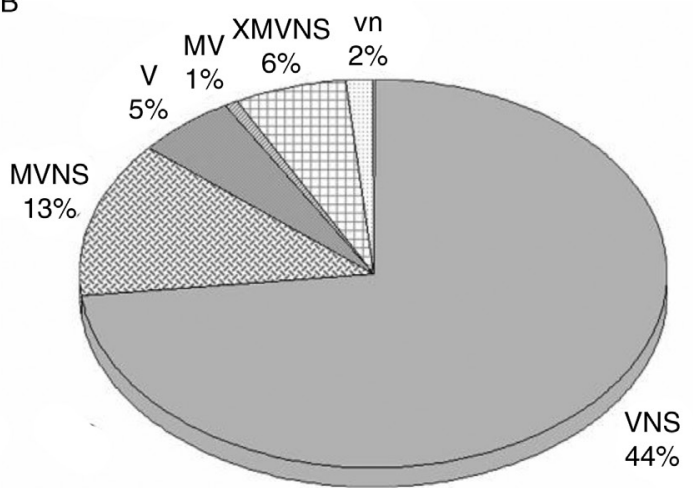

Fig. 3. Distribution patterns: A, global for all the species (A, Austral-Antarctic; AM, American; B, Bipolar; C, Circumsubantarctic; COS, Cosmopolitan; E, Endemic; F, African; N, Neotropical; PAN, Pantropical). B, national for all the species (M, Mediterranean; N, Nord-Patagonic; S, Subantarctic; V, Valdivian; X, Xeromorphic).

The dominant bryo-lichenic flora of peatlands and tepuales coincides in distribution with that of the Valdivian temperate rainforests endemic to southern South America. This suggests a prolonged isolation of the flora (Villagrán \& al., 2003). For example, the Neotropics are one of the areas showing the highest endemicity of bryophytes worldwide - the percentage of endemic species reaches $48 \%$ (Tan \& Pócs, 2000). Consequently, taking as reference the cited study, the $48 \%$ endemic taxa we find in our study places the assessed ecosystems in the range of highest bryophyte endemicity.

The majority of species studied shows a wide distribution in southern Chile; extending along regions X and XII in southern Chile and reaching, in certain cases, region VII in central Chile. This distribution pattern is repeated for most of the bryophytic flora of the archipelago of Chiloé (Villagrán \& al., 2005). This range of distribution, associated with temperate rainforests of southern South America, is considered favorable for the development of groups of cryptogams like the ones studied, due to the conditions that exist there, such as the very humid oceanic climate, the diversity of habitats, and the temperatures moderated by the influence of the sea (Barrera \& Osorio, 2008).

Another relevant issue to highlight is the important number of species that exhibit discontinuity in their national distributional ranges. An important number of disjunct species shows a gap between Chiloé and the forests of Fray Jorge, located in the semi-arid coast of northern Chile. This distributional pattern has been associated with tectonic and climatic events that affected the Chilean territory during the Tertiary and Quaternary, that transformed Fray Jorge into a glacial refuge (Villagrán \& al., 2004).

Finally, measuring the biological diversity, as well as shedding light on ecological theory, provides decision makers with new parameters for issuing recommendations on the conservation of taxa or endangered areas, as well as monitoring the effects of perturbations on the environment (Moreno, 2001). The Convention on Biological Diversity requires that the signatory nations establish an inventory of its biodiversity, monitor changes in the biodiversity, and lay out plans on how biodiversity can be preserved (ONU, 1992). However, Chile is still far from meeting these objectives with regards to bryophytes and macro-lichens, groups that show a lack of basic and descriptive research, which should be tackled in order to establish and adequately manage the natural heritage. Thus, the present study is our contribution towards meeting these requirements.

\section{ACKNOWLEDGMENTS}

This research was supported by grants AECID A/025081/2009, Cooperación al Desarrollo UCM 4138114 and AECID A/030011/2011. We are very grateful to Dr. (c) Alfonso Benítez-Mora for his assistance in the field. We wish to thank the Fundación Senda Darwin, Aserradero A.R.P., Chepu adventures, I. Municipalidad de Dalcahue and CONAF Chiloé for their logistic support during fieldwork; Prof. Gracielle Pereira Rocha at Academic Writing Center, U.S. Embassy, for her assistance with English language editing, and anonymous reviewers for their useful comments and suggestions.

C.A. León acknowledges the support of the doctoral fellowship provided by CONICYT-Gobierno de Chile.

This is a contribution to the Research Program of LTSER-Chile network at Senda Darwin Biological Station, Chiloé, Chile.

\section{REFERENCES}

Andrus, R.E., Wagner, D.J. \& Titus, J.E. 1983. Vertical zonation of Sphagnum mosses along hummock-hollow gradients. Canadian Journal of Botany 61: 3128-3139. http://dx.doi.org/10.1139/b83-352.

Barrera, E. \& Osorio, F. 2008. Briófitas: Musgos, Hepáticas y Antoceros. In: Saball, P. \& al. (eds.), Biodiversidad de Chile. Patrimonio y desafios. 346-351. CONAMA, Santiago, Chile.

Bell, N.E., Quandt, D., O'Brien, T.J. \& Newton, A.E. 2007. Taxonomy and phylogeny in the earliest diverging pleurocarps: square holes and bifurcating pegs. The Bryologist 110: 533-560. http://dx.doi. org/10.1639/0007-2745(2007)110[533:TAPITE]2.0.CO;2.

CABI Bioscience, CBS-KNAW Fungal Diversity Centre \& Landcare Research. 2012. Index Fungorum. http://www.indexfungorum.org/ names/Names.asp.

CONAF. 2009. Plan de Acción Provincial Chiloé - Plan de Gestión Territorial. Oficina Provincial Chiloé - Corporación Nacional Forestal. Castro, Chile.

Crandall-Stotler, B., Stotler, R.E. \& Long, D.G. 2009. Morphology and classification of the Marchantiophyta. In: Goffinet, B. \& Shaw, A.J. (eds.), Bryophyte Biology: 1-54. Cambridge University Press, Cambridge.

Charman, D. 2002. Peatlands and environmental change. J. Wiley \& Sons. London \& New York.

di Castri, F. \& Hajek, E.R. 1976. Bioclimatología de Chile. Editorial Universidad Católica de Chile. Santiago, Chile.

Díaz, M.F., Larraín, J. \& Zegers, G. 2005. Guía para el conocimiento de la flora de turberas y pomponales de la Isla Grande de Chiloé. Fundación Senda Darwin.

Díaz, M.F., Larraín, J., Zegers, G. \& Tapia, C. 2008. Caracterización florística e hidrológica de turberas de la Isla Grande de Chiloé, Chile. Revista Chilena de Historia Natural 81: 445-468. http://dx.doi.org/ 10.4067/S0716-078X2008000400002. 
Feuerer, T. 2012. Checklist of lichens and lichenicolous fungi of Chile. Preliminary version. http://www.biologie.uni-hamburg.de/checklists/ south-america/chile_l.htm.

Galloway, D.J. \& Quilhot, W. 1998. Checklist of Chilean lichen- forming and lichenicolous fungi. Gavana Botánica 55: 111-185.

García, N. \& Ormazabal, C. 2008. Árboles Nativos de Chile. Enersis S.A. Santiago, Chile.

Gignac, L.D. \& Vitt, D.H. 1990. Habitat limitations of Sphagnum along climatic, chemical, and physical gradients in mires of western Canada. The Bryologist 93: 7-22. http://dx.doi.org/10.2307/3243541.

Gignac, L.D., Vitt, D.H., Zoltai, S.C. \& Bayley, S.E. 1991. Bryophyte response surfaces along climatic, chemical and physical gradients in peatlands of western Canada. Nova Hedwigia 53: 27-71.

Goffinet, B., Buck, W.R. \& Shaw, A.J. 2008. Morphology and classification of the Bryophyta. In: Goffinet, B. \& Shaw, A.J. (eds.), Bryophyte Biology: 55-138. Cambridge University Press.

Goffinet, B., Buck, W.R. \& Shaw, J. 2011. Classification of the Bryophyta. http://www.eeb.uconn.edu/people/goffinet/Classificationmosses.html.

Halffter, G. \& Moreno, M. 2005. Significado biológico de las Diversidades Alfa, Beta y Gamma. In: Halffter, G. \& al. (eds.), Sobre Diversidad Biológica: El significado de las Diversidades Alfa, Beta y Gamma: 5-18. M3M-Monografias Tercer Milenio, vol. 4. SEA, CONABIO, Grupo DIVERSITAS \& CONACYT, Zaragoza, España.

Hässel de Menéndez, G. \& Rubies, M. 2009. Catalogue of the Marchantiophyta and Anthocerotophyta from Chile, Argentina and Uruguay. Nova Hedwigia 134: 1-672.

Kleinebecker, T., Holzel, N. \& Andreas, V. 2008. South Patagonian ombrotrophic bog vegetation reflects biogeochemical gradients at the landscape level. Journal of Vegetation Science 19: 151-160. http://dx.doi. org/10.3170/2008-8-18370.

Kleinebecker, T., Hölzel, N. \& Vogel, A. 2010. Patterns and gradients of diversity in South Patagonian ombrotrophic peat bogs. Austral Ecology 35: 1-12. http://dx.doi.org/10.1111/j.1442-9993.2009.02003.x.

Lang, S.I., Cornelissen, J.H.C., Hölzer, A., Ter Braak, C.J.F., Ahrens, M., Callaghan, T.V. \& Aerts, R. 2009. Determinants of cryptogam composition and diversity in Sphagnum-dominated peatlands: the importance of temporal, spatial and functional scales. Journal of Ecology 97: 299-310. http://dx.doi.org/10.1111/j.1365-2745.2008.01472.x.

Larraín, J. 2012. Filogenia del género Racomitrium Brid. (Bryophyta, Grimmiaceae) y taxonomía de las especies latinoamericanas. Grado de Doctor en Botánica. Facultad de Ciencias Naturales y Oceanográficas - Programa de Doctorado en Ciencias Biológicas área Botánica, Universidad de Concepción. Concepción, Chile.

León, C.A. 2012. Caracterización florística y ecológica de turberas esfagnosas de la isla Grande de Chiloé-Chile: una herramienta para la conservación y el desarrollo sostenible. Grado de Doctor. Departamento de Biología Vegetal I, Universidad Complutense de Madrid. Madrid.

León, C.A., Oliván, G. \& Pino-Bodas, R. 2013. New distributional records for the Chilean bryophyte and lichen flora. Gayana Botánica 70(2): 219 224. http://dx.doi.org/10.4067/S0717-66432013000200005.

Malmer, N. 1962. Studies on mire vegetation in the Archaean area of southwestern Götaland (South Sweden). I. Vegetation and habitat conditions on the Åkhult Mire, Lund. Opera Botanica 7: 1-6.

Minayeva, T. 2008. Peatlands and Biodiversity. In: Parish, F. \& al. (eds.), Assessment on peatlands, biodiversity and climate change: main report 60-97. Global Environment Centre, Kuala Lumpur and Wetlands International, Wageningen.

Missouri Botanical Garden. 2014. Tropicos database. http://www.tropicos.org.

Moreno, C.E. 2001. Métodos para medir la biodiversidad. CYTED/ ORCYT - UNESCO/Sociedad Entomológica Aragonesa (SEA). Zaragoza, España.

Müller, F. 2009. An updated checklist of the mosses of Chile. Archive for Bryology 58: 1-124.

ONU. 1992. Convenio sobre la Diversidad Biológica.

Pérez, C.A., Armesto, J.J., Torrealba, C. \& Carmona, M.R. 2003. Litterfall dynamics and nitrogen use efficiency in two evergreen temperate rainforests of southern Chile. Austral Ecology 28: 591-600. http://dx.doi. org/10.1046/j.1442-9993.2003.01315.x.

Rydin, H. \& Jeglum, J.K. 2006. The Biology of Peatlands. Oxford University Press. http://dx.doi.org/10.1093/acprof:oso/9780198528722.001.0001.

San Martín, C., Ramírez, C. \& Figueroa, H. 1999. Análisis multivariable de la vegetación de un complejo de turberas en Cordillera Pelada (Valdivia, Chile). Lazaroa 20: 95-106.
Schlatter, R. \& Schlatter, J. 2004. Los turbales de Chile. In: Blanco, D. \& Balze, V.d.l. (eds.), Los Turbales de la Patagonia: Bases para su inventario y la conservación de su biodiversidad: 75-80. Wetlands Internacional, Buenos Aires, Argentina.

Seki, T. 1974. A moss flora of Provincia de Aisén, Chile. Journal of Science of the Hiroshima University, Series B, Div. 2 (Botany) 15: 9-101.

Stotler, R.E. \& Crandall-Stotler, B. 2011. Liverwort Classification at the Rank of Genus and Above. http://bryophytes.plant.siu.edu/marchantiophyta.html.

Tan, B. \& Pócs, T. 2000. Bryogeography and conservation of bryophytes. In: Shaw, J. \& Goffinet, B. (eds.), Bryophyte Biology 403-448 pp. Cambridge University Press, Cambridge.

Teneb, E. \& Dollenz, O. 2004. Distribución espacial de la flora vascular, humedad y $\mathrm{pH}$ en un turbal de esfagno (Sphagnum magellanicum Brid.), Magallanes, Chile. Anales del Instituto de la Patagonia 32: 5-12.

Teneb, E., Gómez, P. \& González, M. 2008. Observaciones sobre la flora y vegetación de dos turberas en la Región de Aisén, Patagonia Chilena. Gayana Botánica 65: 229-232. http://dx.doi.org/10.4067/ S0717-66432008000200009.

Veblen, T. \& Schlegel, F.M. 1982. Reseña ecológica de los bosques del sur de Chile. Bosque (Valdivia) 4: 73-115.

Villagra, J., Montenegro, D., San Martín, C., Ramírez, C. \& Álvarez, I. 2009. Estudio de la flora liquénica de las turberas de la Comuna de Tortel (región de Aisén), Patagonia chilena. Anales del Instituto de la Patagonia 37: 53-62. http://dx.doi.org/10.4067/S0718 686X2009000100005.

Villagrán, C., Armesto, J.J., Hinojosa, L.F., Cuvertino, J., Pérez, C. \& Medina, C. 2004. El enigmático origen del bosque relicto de Fray Jorge. In: Squeo, F.A. \& al. (eds.), Historia Natural del Parque Nacional Fray Jorge. 3-43. Ediciones Universidad de La Serena, La Serena.

Villagrán, C. \& Barrera, E. 2002. Musgos del Archipiélago de Chiloé, Chile. Corporación Nacional Forestal - Gobierno de Chile. Puerto Montt, Chile.

Villagrán, C., Barrera, E., Cuvertino, J. \& García, N. 2003. Musgos de la Isla Grande de Chiloé, X Región, Chile: Lista de especies y rasgos fitogeográficos. Boletín del Museo Nacional de Historia Natural Chile 52 $17-44$.

Villagrán, C., Barrera, E. \& Medina, C. 2002. Las Hepáticas del Archipiélago de Chiloé, Chile. Corporación Nacional Forestal - Gobierno de Chile. Puerto Montt, Chile.

Villagrán, C., Hässel de Menéndez, G. \& Barrera, E. 2005. Hepáticas y Anthocerotes del Archipiélago de Chiloé. Una introducción a la flora briofitica de los ecosistemas templados lluviosos del sur de Chile. Corporación de Amigos del Museo Nacional de Historia Natural. Santiago, de Chile.

Vitt, D.H. \& Belland, R.J. 1995. The bryophytes of peatlands in continental western Canada. Fragmenta Floristica et Geobotanica 40:339-348.

Vitt, D.H., Crum, H.A. \& Snider, J.A. 1975. The vertical zonation of Sphagnum species in hummock-hollow complexes in northern Michigan. Michigan Botanist 14: 190-200.

Vitt, D.H., Horton, D.G., Slack, N.G. \& Malmer, N. 1990. Sphagnumdominated peatlands of the hyperoceanic British Columbia coast: patterns in surface water chemistry and vegetation. Canadian Journal of Forest Research 20: 696-711. http://dx.doi.org/10.1139/x90-093.

Wheeler, B.D. 1993. Botanical diversity in British mires. Biodiversity and Conservation 2: 490-512. http://dx.doi.org/10.1007/BF00056744.

Wheeler, B.D. \& Proctor, M.C.F. 2000. Ecological gradients, subdivisions and terminology of north-west European mires. Journal of Ecology 88: 187-203. http://dx.doi.org/10.1046/j.1365-2745.2000.00455.x.

White, J. \& James, P.W. 1985. A new guide to microchemical techniques for the identification of lichen substances. Bulletin of the British Lichen Society 57: 1-41.

Zegers, G., Larraín, J., Díaz, M.F. \& Armesto, J.J. 2006. Impacto ecológico y social de la explotación de pomponales y turberas de Sphagnum en la Isla Grande de Chiloé. Revista Ambiente y Desarrollo 22: 28-34.

Associate Editor: Lisa Pokorny Received: 26-II-2013 Accepted: 8-VII-2014 